\title{
Comparative Analysis of the Russian and European Systems of Education for Tourism Industry Training
}

\author{
Vasiliy Gerneshiy ${ }^{1, *}$ \\ ${ }^{1}$ Peoples' Friendship University of Russia (RUDN University), 6 Miklukho-Maklaya Street, Moscow 117198, Russia \\ "Corresponding author. E-mail: v.gerneshij@yandex.ru
}

\begin{abstract}
The article reveals results of the theoretical generalization of studies concerning the Russian and foreign systems of higher education of personnel training for tourism. The author considers European systems as the exemplars boasting historical experience and sustainability in preparing the personnel for the tourism industry. The researcher reveals conditions and factors influencing the educational policies of teaching specialists and elaborates requirements to such systems as stated by the professional community. The paper concludes with the proposals for the use of positive foreign experience for implementing them into the schooling activities of Russian universities.
\end{abstract}

Keywords: tourism industry, educational system and organization, professional training, dual education,

bachelor's degree programs, master's degree programs, personnel training

\section{INTRODUCTION}

Over nine years from 2010 to 2019, revenues from tourism services have reached (and sometimes even exceeded) those of oil, food, or car exports. Travel has turned into a significant player in international trade and, simultaneously, has become a source of income for certain countries. United Nations World Tourism Organization (UNWTO) forecasts further sustainable growth [1].

The challenge, however, is that an adequate human capital base is required to support the expected growth and to achieve competitiveness and sustainability of the sector. Quite obviously, the contribution of tourism to the economic wellbeing of a state depends on the quality and revenues of supply. The supply's quality, attractiveness, and liquidity depend on a certain degree on the level of competence and qualification of people involved in the process.

In five to seven years, we are to witness the emergence of new types of businesses, products, services, and professions that require various competencies, knowledge, hard, and soft skills. One of the significant factors causing changes is the digitalization in the economy and the travel industry in particular. Digital technologies are radically changing and have already changed the familiar world, predetermined the implementation of the principles of

*Fund: The reported study was funded by RFBR, project number 20-011-00045 A "The Influence of Ethnocultural, Religious, Communicative, Educational and Migration Factors on the Development of the Contemporary Tourism Industry: SocioPhilosophical Inquiry." the fourth industrial revolution [2].

The quality of tourism offer shortly will depend crucially on the latest technologies, acting as a platform for digital economies [3], such as Big Data, cloud services, machine learning, smart technology, geolocation, Internet of Things, Industrial Internet of Things, and 3D-printing.

Just as new tech changes the style of us traveling, it also influences the requirements for the qualification of specialists involved, adapting the content of their activities, determining the emergence of new professions and competencies. With a certain amount of confidence, we may say that the development of global tourism and digitalization of the economy have actualized the issue of personnel training in all the sectors of the economy, from production and service to life-long education. And it is the pedagogy that forms the human resources potential globally as a specific set of knowledge, skills, and professional competencies used to meet a wide range of consumer demands.

\section{EUROPEAN EDUCATIONAL SYSTEMS FOR TOURISM INDUSTRY TRAINING}

Growing requirements for the staff potential necessitate the identification of standard features and differences in the development of Russian and foreign tourism schools. Some countries, such as Finland, Austria, France, Germany, Switzerland, and the United Kingdom, have accumulated considerable expertise in professional training of personnel for the industry. 
The peculiarity of Finland is the broad application of $R \& D$ results for the development of local tourist destinations. The most significant number of people almost half of them, $48 \%$ - is employed in the restaurant sector, the smallest - in travel agencies and hospitality.

According to the Travel \& Tourism Competitiveness Index (TTCI), Finland has one of the best performance indicators among the world educational systems [4]. A distinctive feature of the Finnish system is its comprehensive representation and accessibility for the country's adult population. There are several forms of learning:

- Colleges and public schools;

- Open, summer universities;

- Open polytechnic universities.

These institutions are part of the Finnish Adult Education Association, thus ensuring a high level of centralization and structuration in the country.

If we consider the content of training programs of different levels in the field of tourism in Austria, implemented in more than 30 facilities, we can identify the conceptual foundations of vocational education in this country, expressed in terms of theory and practice, the relationship among different learning levels and ensuring comprehensive learning at all levels.

The provision of comprehensive quality assurance in tourism training is carried out to form measurable universal, methodological, and professional competencies at each level. Quality assurance of professional skills is done by using national tests. Noteworthy, the standard of higher education is developed jointly with several neighboring countries.

We should also highlight the leading role of dual programs in Austria. Such practice is known to take place at the same time in a company and a school or university. Dual education in Austria is divided unevenly: up to $80 \%$ of the time is spent at a tourist enterprise and only 20\% - at an HEI. Students participating in the dual education system, perform specific professional duties, and receive a scholarship from a company.

However, we should take into consideration that in the Austrian dual training, one can obtain a profession related to the performance of activities only up to the $4^{\text {th }}$ qualification level out of 8 European qualification levels. Higher levels require higher degrees of responsibility on the part of an employee and require a different approach. The concept of lifelong education is reflected in various forms of vocational training.

France is an active tourist destination with over 85 mln arrivals registered annually. After a short analysis of the French educational system for the tourism industry, we may highlight several important traits: professional tuition is present at the $2^{\text {nd }}, 3^{\text {rd }}$, and postgraduate levels.

At the $2^{\text {nd }}$ level, there are vocational schools and training centers with 2-3 years of study. There are mainly practice-oriented programs with a diploma qualification: $\mathrm{CAP}$ - diploma of professional qualification, BEP - diploma of general professional development.

At the next step, there are technical schools and institutes of technology where one studies for two years with a graduate receiving a diploma of qualification. Sometimes this level is called a "short cycle of higher education," BTS in tourism - the 4th level of qualification/profession: guide, travel agent, travel consultant, etc. At the higher level, there are two levels of "licentiate" — an analog of bachelor and master's degrees.

Licentiate comprises three years of guidance. To enter this type of program, a person must have a B.Sc. diploma, obtained as a result of completing a long (lyceum) cycle of high school. Bachelor's graduate from humanitarian, natural science, and economic profiles. A personal trajectory at the lyceum niveau allows passing the STT diploma examination, confirming the mastery of competencies in the service sector. Master's programs also offer options: one-year without specialization for 60 ECTS and two-year with specialization for 120 ECTS. MBA is also popular. The doctorate (Doctorat) level is the official level in the French system, with the successful defense of a thesis ending with the awarding of a Docteur degree. There are variations at different levels of professional tutoring in France: long or short training cycle, profiling, different trajectories for mastering the competencies.

The peculiarity of the French model of personnel training for the tourism industry lies in the sophisticated system of inter-institutional relations, provided in the regulatory framework, and the regulation of the content of educational programs.

A distinctive feature of tourism management in the United Kingdom is its certain autonomy. The government entrusts the tasks of travel development and design of similar activities to independent tourist organizations and business communities (Local Enterprise Partnerships). The professional training in the British tourism industry is based on professional standards (National Occupational Standards) that determine the content of programs. There is a centralized system of implementation of the qualification and professional structure in the content of vocational training. Its content is designed based on the Qualifications and Credit Framework. Qualifications consist of sections, the content of crucial competencies 
expressed in credits - actual training time required to master them in each section.

The British model aims at meeting the actual needs of the compensational traits of professionals. Another distinctive feature is the orientation on individual choice of a student: mechanics of professional direction and adaptation are, in fact, self-regulative and independent from the government.

We should stress, however, that the humanizing principles are less inherent to the British system: early career guidance, focus on self-development, lifelong education is more common to the Austrian or Finnish models. Perhaps, this also leads to the bachelors' employment rate: less than $40 \%$ of them are employed in the corresponding field, and an unemployment rate of the graduates is quite high, reaching 9\% [5].

The peculiarity of Swiss education in tourism is its active export to other countries, testifying of its high quality: according to the statistics of the Swiss National Statistical Office, $30 \%$ of the students are foreigners [6]. There are, however, issues in personnel management at the apprenticeship level. According to Swiss specialists, low-status levels of interns in tourism and hospitality lead to a lack of students' motivation.

The state of the structure and content of applied tuition in Switzerland in the context of the processes of ensuring a high level of quality training for the industry at different levels of learning suggests that the personnel schooling at the secondary qualification levels is provided through a purely practice-oriented approach.

Swiss institutions emphasize the need to maintain and improve their quality assurance parameters, which in turn are subject to certification. It is governed by the EDUQUAL1 system, and, additionally, the Swiss schools are certified under the Quality Seal of Approval for Swiss Tourism (Qualitäts-Gütesiegel für den Schweizer Tourismus), that encompasses travel companies, involved in service quality and customer focus. The initiative was developed by the Swiss Tourism Union in cooperation with academic institutions.

The German model for tourism education is quite evident in its external differentiation in applied and academic fields. Academic training is provided by classical universities and applied sciences institutes. Maximum opportunities for professional cultivation are carried out through dual programs. The peculiarity of this form, focusing mainly on the mastery of practical competencies directly at a workplace, is that most graduates require further guidance in order to expand acquired skills to ensure better career trajectories at a volatile market and to ensure vertical social mobility [7].
Germany presents the approach, combining the academic and applied approaches. The dual-type provides the highest possible opportunities for professional socialization. German universities implement tourism direction on the basis of natural sciences or humanities, such as geography, economics, history, and cultural studies. The training uses several principles, including but not limited to fundamental, essential competencies related to obtaining, processing, and interpretation of information, ideas generation, and project development. Applied bachelor students focus on the elaboration of specific topics.

\section{PERSONNEL TRAINING FOR TOURISM INDUSTRY IN RUSSIA}

Tourism in Russia is a relatively new direction in the system of preparation of higher and secondary vocational education. Tourism and hospitality in Russia have undergone significant changes in recent years, with technologies, legal regulations, and digitalization changing rapidly to tie in qualitatively with their global counterparts [8]. Surely, in such conditions, training should be innovative and be ahead of the curve.

The strategy for tourism development in the Russian Federation for the period up to 2035 [9] defines that to achieve a high level of service, the industry requires a comprehensive approach in terms of creating conditions to ensure it with a sufficient number of qualified personnel. Besides, to increase the efficiency of this sphere of the economy by ensuring the quality of services rendered, products generated, as well as hospitality at the level of the best world practices, the strategy provides for adjustment of mechanisms for meeting future needs in human resources, long-term planning and construction of the personnel guidance system at all levels.

Referring to the best international experience of guidance and basing on the applied nature, flexibility and dynamically changing sphere of the tourism industry in national educational systems should support the fact that travel activities require innovative and nontraditional approaches to schooling. Currently, HEIs carry out the training of personnel for the tourism industry in three directions designed by the Ministry of Science and Higher Education that are Service, Tourism, and Hospitality at bachelor's and master's levels. We should note that the training bases on a competence model closely linked to the professional standards of the field of upcoming professional activities. At the bachelor's level, there are four years of study (240 ECTS), and there are two years at the master's level (120 ECTS).

Despite a specific regulation by the federal standards, universities and institutes have the right to determine a profile, i.e., orientation independently. 
Besides, an educational organization may independently determine up to $90 \%$ of the scholarly disciplines of a program [10]. Not only the list of subjects but also the amount of time allocated for their study, types of classes, and forms of control over the students' mastery of disciplines and the formation of competencies. This approach diversifies the quantity and quality of offered programs significantly, allows to respond adequately to the requirements of the regional tourism business, to adapt to changing conditions of the local and world economies. There is a decisive element in Russian tourism that the structural and logical schemes of programs are inter- and multidisciplinary.

\section{CONCLUSION}

Despite quite obvious successes in tourism education achieved in a relatively short time, there are challenges yet to face, including new global trends, emerging university and business clusters, gamification, high-level competitiveness, and rapid development of industries. There is also a steady trend of the gradual transformation of labor in the world economy with people striving to change their occupation once every five years, raising even more issues.

Technology in contemporary tourism is changing way too fast, and, as a result, professional knowledge rapidly becomes obsolete. Some of the knowledge obtained at the universities may become outdated even before graduation. Every year more than 500 professions "die out," and some 600 new professions emerge, with the dynamics only increasing [11].

In some industries, innovation cycles are shorter than the time required to prepare specialists. In the IT or travel spheres, e.g., innovation cycles are more concise than the time necessary for an individual to get used to new tech. In connection with the latest trends, there are new requirements for the formation of new competencies. Essentially, the system of personnel development for the tourism industry faces unique challenges that will require, respectively, new solutions in the implementation of educational programs and non-standard approaches and methods.

\section{References}

[1] UNWTO, 2020 [Online]. Available: https://www.unwto.org/global-and-regional-tourismperformance. [Accessed 6 April 2020].

[2] Chistyakov, D.I., Media Praxis in Constructing Symbolic Space: Intercultural Approach, в Proceedings of the 4th International Conference on Contemporary Education, Social Sciences and Humanities (ICCESSH 2019). Series: Advances in Social Science, Education and Humanities Research, Paris, 2019.

[3] Leshkevich, T.G., Digital Transformation of the Era in the Projection of Their Impact on the Modern Man, Tomsk State University Journal, т. 439, pp. 103-109, 2019.
[4] World Economic Forum, The Travel \& Tourism Competitiveness Report 2017, The Travel \& Tourism Competitiveness Report 2017, 5 April 2017. [Online]. Available: https://www.weforum.org/reports/the-travel-tourismcompetitiveness-report-2017. [Accessed 6 April 2020].

[5] Office for National Statistics, Employment and Employee Types, Office for National Statistics, [Online]. Available: https://www.ons.gov.uk/employmentandlabourmarket/peoplein work/employmentandemployeetypes. [Accessed 7 April 2020].

[6] Federal Statistical Office (Switzerland), Students at universities of applied sciences. Part of female and foreign students, Federal Statistical Office (Switzerland), 25 March 2020. [Online]. Available:

https://www.bfs.admin.ch/bfs/en/home/statistics/educationscience/pupils-students.assetdetail.12307983.html. [Accessed 7 April 2020].

[7] Chistyakova, O.V., Philosophical Reflection on Tourism in a Context of Global Intercultural Communications, в Proceedings of the 2019 International Conference on Contemporary Education, Social Sciences and Ecological Studies (CESSES 2019, Moscow, 2018

[8] Pasko, O. V. Gerneshiy и I. Suvorova, Collaboration and Causerelated Marketing in Eco-friendly Hospitality, в Proceedings of the 2nd International Conference on Contemporary Education, Social Sciences and Ecological Studies (CESSES 2019), 2019.

[9] Federal Agency for Tourism (Russia), The Strategy for Tourism Development in the Russian Federation for the Period Up to 2035, 20 September 2019. [Online]. Available: https://www.russiatourism.ru/contents/otkrytoe_agentstvo/strate giya-razvitiya-turizma-v-rossiyskoy-federatsii-v-period-do2020-goda-332/strategiya-razvitiya-turizma-v-rossiyskoyfederatsii-v-period-do-2035-goda/. [Accessed 6 April 2020]

[10] Ponizovkina, I., Teaching of Philosophy as a System of Modern Higher Education, B Proceedings of the 2017 2rd International Conference on Contemporary Education, Social Sciences and Humanities, 2017.

[11] Pirogova, O.V., Tourism Education Development Prospects, 2016. [Online]. Available: http://scienceeducation.ru/ru/article/view?id=25706. [Accessed 6 April 2020].

[12] Ministry of National Education (France), Ministry of National Education $\quad$ (France), [Online]. Available: www.education.gouv.fr. [Accessed 6 April 2020].

[13] German Federal Ministry of Education and Research, German Federal Ministry of Education and Research, [Online] Available: https://www.bmbf.de/en/index.html. [Accessed 6 April 2020]. 